\title{
Павловский В.С. \\ О необходимости принятия федерального закона об основах государственной национальной политики Российской Федерации
}

Институт законодательства и сравнительного правоведения при Правительстве Российской Федерации (Россия, Москва)

doi: $10.18411 / l j-31-01-2018-39$

idsp: 000001:lj-31-01-2018-39

\section{Аннотация}

В статье рассматривается необходимость принятия федерального закона об основах государственной национальной политики Российской Федерации, описывается ход научной дискуссии по соответствующему вопросу. Автор приходит к выводу о том, что принятие федерального закона об основах государственной национальной политики будет способствовать эффективной координации деятельности органов публичной власти различных уровней по достижению целей и задач, обозначенных Стратегией государственной национальной политики Российской Федерации на период до 2025 года.

Ключевые слова: федеральный закон, полномочия, органы публичной власти, государственная национальная политика

\section{Abstract}

The article deals with the need to pass a federal law dedicated to the Russian State's National Policy. The scientific discussion about this issue is described. The author comes to the conclusion that passing a federal law about the main aspects of the Russian State's National Policy could help to coordinate the activity of public authorities in Russia and to reach the objectives which marked in the Strategy of the State's National Policy of the Russian Federation before 2025.

Keywords: federal law, competence, public authorities, state's national policy.

После утверждения Указом Президента РФ от 19 декабря 2012 г. № 1666 Стратегии государственной национальной политики Российской Федерации на период до 2025 г. был образован федеральный орган исполнительной власти, наделённый широкими полномочиями в сфере осуществления национальной политики и проведения мониторинга этапов её реализации - Федеральное агентство по делам национальности (далее - ФАДН, Агентство). По словам руководителя ФАДН, при создании Агентства в 2015 г. планировалось, что для выполнения поставленных задач оно будет располагать представительствами в федеральных округах, подведомственными структурами. Этому помешала сложная экономическая ситуация, поэтому в настоящий момент главный контрагент ФАДН в субъектах РФ - их исполнительная власть, которую Агентство убеждает создавать структурные подразделения, занимающиеся реализацией национальной политики. Есть проблемы и по взаимодействию между ФАДН и другими федеральными органами исполнительной власти. Сегодня реализацией мероприятий в сфере национальной политики в той или иной мере занимаются девятнадцать федеральных исполнительных органов. На координацию их совместной деятельности в поле национальной политики уходят значительные средства, а видимый результат достигается, к сожалению, не всегда, поскольку нет единого центра взаимодействия, в работе федеральных исполнительных органов не всегда учитывается этноконфессиональные факторы.

В связи с этим в последнее время учёные-правоведы, политики и общественные деятели всё чаще обращают внимание на необходимость принятия федерального закона, который упорядочивал бы усилия публичных органов разного уровня в решении вопросов национальной политики, устанавливал основы их сотрудничества с институтами 
гражданского общества и одновременно признавал направляющую роль ФАДН во всех соответствующих вопросах. Пока же имеется Стратегия государственной национальной политики (не осуществляющая нормативного регулирования и не имеющая за собой государственного принуждения), образовано ФАДН, а нормативного правового акта, на основании которого осуществлялось бы государственное управление в области межнациональных (межэтнических) отношений, которым руководствовалась бы вся система органов публичной власти, нет.

Как полагают Л.Ф. Болтенкова и Е.И. Рябова, «ссылаться на Положение о ФАДН несерьёзно. Агентству приходится контактировать по роду своей деятельности с десятками других государственных (и негосударственных) структур как по горизонтали, так и по вертикали (которую, кстати, нужно ещё создать, не забывая, что Россия федеративное государство). Такие вопросы решаются в опоре на закон».

Действительно, в обществе ощущается недооценка значения государственной национальной политики. Возможно, законодательное регулирование соответствующих вопросов смогло бы изменить ситуацию. По мнению С.А. Авакьяна, «национальногосударственные отношения заслуживают того, чтобы посвящённые им нормы Конституции РФ получили развитие в специальном федеральном законе об основах государственной национальной политики».

При этом, как отмечает руководитель ФАДН, «это будет сложный закон. Предмет его регулирования нельзя «пощупать». Это не закон о здравоохранении или закон о природных ресурсах, когда в принципе область регулирования понятна и нужно просто определить приоритеты. Здесь мы говорим об иных вещах - нематериальных. В законе в первую очередь нужно определить основную терминологию и понятия. Ведь до сих экспертное сообщество не пришло к общему мнению даже по основным понятиям». Закон, таким образом, призван определить понятийный аппарат, разграничить полномочия (за что отвечают федеральные публичные структуры, за что региональные, а за что - местные), сферу ответственности всех субъектов реализации государственной национальной политики. Возможно, будут определены критерии оценки эффективности деятельности органов исполнительной власти. Обсуждаемый закон должен не создавать в национальной политике новые идеи и смыслы, а, скорее, систематизировать механизмы её реализации.

С актуальностью принятия федерального закона об основах государственной национальной политики согласно большинство учёных, представляющих разные области знания. Так, 22 апреля 2016 г. на заседании Совета по межнациональным отношениям и взаимодействию с религиозными объединениями при Совете Федерации Федерального Собрания РФ в пользу принятия соответствующего федерального закона высказались Г.К. Сафаралиев, В.А. Михайлов и В.А. Тишков. Они подчеркнули, что назрела объективная необходимость принятия закона об основах государственной национальной политики и о межэтнических отношениях. Предметом его регулирования должны стать индивидуальные права граждан и коллективные права народов по основным направлениям национальной политики, разграничение полномочий и сфера ответственности субъектов власти за её реализацию. Сам закон должен иметь рамочный характер.

Высказывается мнение и о том, что в принятии единого федерального закона о национальной политике нет необходимости. Например, А.Е. Жарников ещё в 2001 г. задавал вопрос: «можно ли в такой этнически многообразной стране, как Россия, принять общий закон, подходящий для всех и при этом учитывающий всю имеющуюся здесь проблематику? Даже в одном субъекте Федерации, и то бывает трудно принять единый законодательный документ, касающийся жизни и проблем проживающих там народов. Что же тогда говорить о всей России?» Предпочтительным, по мнению учёного, выглядит путь дальнейшего совершенствования нормативной правовой базы, связанной со сферой 
национальных отношений, т.е. путь дальнейшей разработки и принятия пусть более узких, но зато глубоко проработанных федеральных законов, касающихся конкретных тем национальной политики.

Следует согласиться с тем, что федеральный закон об основах государственной национальной политики страны необходим. Идеи и концепции, приоритеты и цели, обозначенные Стратегией государственной национальной политики до 2025 г., руководящая роль ФАДН, принципы и механизмы его взаимодействия с публичными структурами различных уровней должны найти своё отражение в рамочном федеральном законе, который упорядочил бы и скоординировал усилия Федерации, её субъектов и муниципальных образований по реализации национальной политики. В федеральном законе также могли бы найти отражение формы участия граждан и общественных объединений в реализации национальной политики.

$$
\text { *** }
$$

1. Указ Президента РФ от 19 декабря 2012 г. № 1666 «О Стратегии государственной национальной политики Российской Федерации на период до 2025 года» // Собрание законодательства РФ. 2012. № 52. Ст. 7477.

2. Указ Президента РФ от 31 марта 2015 г. № 168 «О Федеральном агентстве по делам национальностей» // Собрание законодательства РФ. 2015. № 14. Ст. 2106.

3. Аваакьян С.А. Некоторые мысли о состоянии и перспективах конституционно-политического развития России // Вестник Московского университета. Серия 11. Право. 2016. № 1. С. 3-17.

4. Баринов И.В. Лицо уважаемой национальности // Российская газета. 2016. 23 сентября.

5. Баринов И.В. Термин «российская нация» не предполагает борьбу с инакомыслием // URL: http://fadn.gov.ru/news/2016/11/21/3020-termin-rossiyskaya-natsiya-ne-predpolagaet-borbu-s-inakomysliem (дата обращения: 10 декабря 2017 г.).

6. Болтенкова Л.Ф., Рябова Е.И. К вопросу о государственной национальной политике // Этносоциум. 2016. № 12 (102). С. 16-20.

7. Выступление доцента кафедры национальных и федеративных отношений РАГС при Президенте РФ А.Е. Жарникова о проекте Федерального закона «Об основах государственной национальной политики Российской Федерации» (по материалам «круглого стола») // URL: http://iam.duma.gov.ru/node/8/4427/14506 (дата обращения: 10 декабря 2017 г.)

8. Стенограмма заседания Совета по межнациональным отношениям и взаимодействию с религиозными объединениями при Совете Федерации на тему: «Совершенствование механизмов реализации государственной национальной политики Российской Федерации на период до 2025 года» // URL: http://www.council.gov.ru/events/news/67019/ (дата обращения: 10 декабря 2017 г.)

\section{Цветков А.O. \\ Правовое положение военнопленных армии Карла XII пребывавших на территории России в период Северной войны (1700-1721гг).}

doi: $10.18411 / \mathrm{j}-31-01-2018-40$

(Россия, Омск)

idsp: 000001:lj-31-01-2018-40

\section{Аннотация}

С формированием общего правового статуса личности неизменно получил развитие и специальный правовой статус, статус военнопленного. Параллельно с общеевропейским процессом становления правового положения военнопленного, в России развивалась собственная правовая традиция обращения с данной субъектной группой, которая имела характерную особенность, проявившуюся в период Северной войны (1700-1721гг). Этот опыт очень важен для истории военного плена и правового положения военнопленного, так как, впервые, России пришлось столкнуться с большим наплывом иностранцев, шведов, англичан, немцев которые в качестве военнопленных размещались в различных областях Российской империи.

Ключевые слова: Северная война, плен, военнопленный, правовой статус личности, особенности содержания в плену. 